\title{
Weed plants used as bioindicators of special soil characteristics
}

\begin{abstract}
Weed plants offer a lot of useful information for crop management, so it is important to recognize some cases where their properties as bio indicators of soil quality are observed. Despite the fact Bajio is an important region for mexican agriculture, weeds are littleknown as tools for monitoring the properties of an agroecosystem. Interviews to farmers were made to know their experience on weed flora, complementing the above, appreciations of the biodiversity weed knowledge are exposed. The documentation of the selected species in this work shows that weed plants can provide useful information to farmers for the management of soils and crops. A greater knowledge about the diversity of weeds can generate sustainability índices for the agroecosystems.
\end{abstract}

Keywords: weeds, agroecosystems, soils, Guanajuato, traditional knowledge, agroecology
Volume 5 Issue I - 2021

\author{
Luis Felipe Ramírez-Santoyo,' Rafael \\ Guzmán-Mendoza,' Adrián Leyte-Manrique, ${ }^{2}$ \\ Manuel Darío Salas-Araiza' \\ 'Department of Agronomy, Division of Life Sciences, Campus \\ Irapuato-Salamanca. University of Guanajuato, Mexico \\ ${ }^{2}$ Biology Laboratory (Research and Postgraduate), Tecnológico \\ Nacional de México, Mexico
}

\begin{abstract}
Correspondence: Rafael Guzmán-Mendoza, Department of Agronomy, Division of Life Sciences, Campus IrapuatoSalamanca. University of Guanajuato, Mexico, Tel 462624I889, Email rgzmz@yahoo.com.mx
\end{abstract}

Received: January 06, 2021 | Published: January 18, 202

\section{Introduction}

Since long time, humanity through the systematic observation of natural phenomena has established some references from their practical observations. With the emergence of a sedentary civilization and the consequent performance of agricultural activities, humanity had the opportunity to observe patterns that were repeated throughout the duration of agricultural cycles and to generate sowing schedules, as well as a greater knowledge of the sites. ${ }^{1}$ The domestication of wild plants, and their use in the production of vegetal food, for example, weeds such as "quelite", which in the central region of Mexico, encompasses both food and medicinal uses. To which must be added that the weed flora represents $12 \%$ of the floristic richness of the country. ${ }^{2}$

Today and from an agroecological perspective these plants, rather than being considered as weeds, represent a biological entity that increases the heterogeneity of the agricultural land scape, and provide various ecosystem services as a refuge for beneficial insects, regulation of microclimates, pollination, captures of carbon, recycling of nutrients and minerals, ${ }^{3}$ prevent soil erosion, ${ }^{4}$ among others. For this reason, weed vegetation must be revalued as an indicator element of the agroecosystem, since its presence in crops is capable of pointing out the first signs of the manifestation of a significant change in the soil, ${ }^{5}$ since they can indicate from the presence of some abundant element in the soil system, up to the accumulation of ions of alkaline or alkaline earth characteristics coming from the irrigation waters or the soil and being used in the evaluation of the risk of soil salinization. ${ }^{6}$

The guanajuatense Bajio is a región with intense agricultural activity from a comercial point of view, intensive mono cultures and agro chemical inputs, particularly herbicides and insecticides with their recognized toxic effects on the environment and biological diversity, many of these products are, banned in other countries, in the particular case herbicides, more than $66 \%$ of the products are highly toxic. ${ }^{7}$ This has led to the environments of the shoal to a state of ecological degradation. In this sense, the agroecological traits of the weed plants should be valued and some examples rescued, which, from the experience of the agricultural producers of the Bajío region, are used in a traditional way when making decisions about the work or the acquisition of land, this information is useful but scarce. In this brief review some cases are cited.

\section{Material and methods}

The review work is based on interviews with farmers in the rural area of Bajio guanajuatense over their documented experiences with topics on weeds. The interviews were conducted during field visits, from May 2010 to November 2020. From the information obtained striking the appearance of certain species of weeds that are useful to know the physical conditions, such as altitude and soil, that occur in a plot. These data have a certain degree of support, as part of the knowledge expressed by farmers is supported by empirical observations referred to in specialized literature.

Those plants recognized by farmers as important, they were described and sheltered in the Herbarium of DICIVA (División de Ciencias de la Vida by its spanish name) of Guanajuato University. Since the knowledge of the richness and diversity of the weed flora is poorly documented in the portion of the Bajio, monitoring has been carried out in intensive agriculture plots, the appraisals of this the results are part of this review on the subject of weeds for a agricultural area of food and economic importance for Mexico that faces a biodiversity crisis in its agroecosystems due to the in appropriate use of herbicides.

\section{Results and discussion \\ “Cazahuate" and nopalcrop}

The cazahuate (Ipomoea arborescens, Convolvulaceae) is often used empirically by farmers in the state of Guanajuato as an altitude indicator, that is, with it they determine if a land is susceptible to frost, because these trees develop on the border agroecological-ecotonal zone-with the low deciduous forest, and as the elevation exceeds 1800 meters above sea level, this species is giving way to those with a more 
temperate climate. ${ }^{8}$ This data is very useful when establishing nopal orchards, so some Opuntia sp. producers such as in the locality of Valtierilla, municipality of Salamanca, base the establishment of their nopal plots, in high places, where previously they were had hunt, this with the intention of preventing frosts that could affect the crop.

\section{Astragalus sp. and selenium in soil}

As documented case since the decade of the forties in the region of the north east of Irapuato, the presence was reported high concentrations of selenium in some soils and aquifers, so cattle were intoxicated with the so-called evil of the "Soliman ", which consists of nervous spasms and tremors with erratic gait. In these soils the presence and abundance of plants of the genus Astragalus spp. (Fabaceae), where the association between selenium and plants has been reported. ${ }^{8}$

\section{"Quelites cenizos" Chenopodium album (Chenopodaceae) and soil salting}

Ash chelites are used in some regions of Mexico as food, they are also used as indicators of the presence and accumulation of salts, particularly sodium salts in the soil. When farmers observe the abundance of ash chelites in a field, which is correlated with salt crusts on the surface, and if there are such superficial accumulations or whitish-colored salt crusts, they will indicate the presence of sodium bicarbonate, from the irrigation water or soil. A more serious case is if these crusts are blackish in color, then sodium carbonate can be suspected, if this is the case, the ash chelites present will even have a very small size, in addition they will manifest redness on the leaves which will indicate the content predominantly high sodium and alkalinity in the soil, urging to carry out some treatment measure, for the agricultural recovery of the soil. ${ }^{6}$

\section{Case of coquillo and the amount of soil clay}

The presence and abundance of Cyperus esculentus and Cyperus rotundus (Cyperaceae) have a positive correlation with the percentage of soil clay, (in the vertisols of the Guanajuato shoal this percentage of clay is always above $25 \%$ ). Conversely, the content of organic matter contributes to the decrease in the presence of this plant, mainly due to the action of saprophytic fungi that attack the propagules of Cyperus. At the same time, the increase in soil organic matter facilitates the complete manual extraction of the plant in conjunction with its resistance structures. ${ }^{9,10}$

\section{Bighead grass and removals of land}

Heliopsis annua (Asteraceae), a close relative of the plant called Chicuague (Heliopsis longipes) which has medicinal use by the population of the northwestern state of Guanajuato, for the content afininas. The presence of $H$. annua, shows the disturbance in the cultivation plots, when removal work or earth movements are carried out; These actions contribute to the appearance of the species in the next cycle, mainly due to the fact that the seed bank present in the soil is exposed and this plant occupies the spaces given by others by tillage or earthwork. ${ }^{10,11}$

\section{How many species weed are there in Guanajuato?}

In both Guanajuato and Bajio región there is not enough informationon richness and diversity of weed plants, most of literature focuses on control and eradication of these plants in crops, so its is promoted. This practice has resulted in persistence of increasingly resistant and competitives pecies such as Phalaris minor (Poaceae), which is a major problem in wheat crops, ${ }^{12}$ and wild oat (Avena fatua), which has generated resistance due to continuous herbicide applications. ${ }^{10,13}$ Preliminary observations made by the authors suggests a high endemic weed diversity in the Bajio region, that diversity level might be superior than levels reported in studies carried out in agro ecosystems with less production pressure and consequently less technical and of local-traditional use such as the "milpas". This suggests that agroecosystems have been resilient to herbicide applications and that they still conserve elements that guarantee their sustainability. ${ }^{14}$

\section{Final considerations}

Weed plant species coexist in agricultural crops, which can provide useful information for the farmer, allowing him to know the environmental conditions of the site present in the plot. However, this peasant knowledge is little systematized in most of the agricultural areas of Mexico. Additionally, these diagnostic tools, borned from traditional knowledge to the soil status will help and lead you to carry out the appropriate work and amendments to enrich the physicochemical properties of the soil, so that the plants associated with the crops not only represent a set of antagonistic competitors, but can also be a valuable resource that can be used as an element of diagnosis and management to improve the environmental edaphic conditions, as well as in decision-making in the way that crops will be carried out. In the guanajuatense Bajio there is little documented information on the subject of indicator plants and there are even few systematized agroecological studies that provide data on the functional properties that plants exert on the soil and on the ecological processes that occur in agroecosystems.

\section{Acknowledgments}

Authors want to thank to Farmers interviewed.

\section{Conflicts of interest}

Authors declare no conflict of interest exists.

\section{References}

1. Ocampo-Fletes I, Escobedo-Castillo JF. Traditional knowledge and peasant strategies for the management and conservation of irrigation water. Ra Ximhai. 2006;2:343-371.

2. Martínez-De la Cruz I, Vibrans H, y Lozada-Pérez L. Plantas ruderales del área urbana de Malinalco, Estado de México, México. Botanical Sciences. 2015;93;907-929.

3. Bengtsson J, Ahnström J, Weibull AC. The effects of organic agricultura on biodiversity and abundance: a meta-analysis. Journal of Applied Ecology. 2005;42:261-269.

4. Blanco Y, Leyva Á. Las arvenses en el agroecosistema y sus beneficios agroecológicos como hospederas de enemigos naturales. Cultivos Tropicales. 2007;28:21-28.

5. Moreau D, Pointurier O, Nicolardot B, et al. In which cropping systems can residual weeds reduce nitrate leaching and soil erosion?. European Journal of Agronomy. 2020;119:126015.

6. Aceves NE. El ensalitramiento de los suelos bajo riego biblioteca básica de agricultura. Colegio de Postgraduados-Editorial Mundiprensa, México. 2011.

7. Bejarano GF. Los plaguicidas altamente peligrosos en México. red de acción sobre plaguicidas y alternativas en México, AC. (RAPAM), Texcoco, Estado de México, México. 2017.

8. Roque GJM. Efectos tóxicos del selenio contenido en plantas de garbancillo (Astragalussp.), sobre la salud de animales de cría en el Departamento de Ancash. Tesis Doctoral, Universidad Nacional Santiago Antúnez de Mayolo, Huaraz-Ancash, Perú. 2018. 
9. García BFJ, Roselló CJ, y Santamarina SMP. Introducción a funcionamiento de las plantas. Editorial Universidad Politécnica de Valencia, España. 2006

10. Foxcroft LC, Pyšek P, Richardson DM, et al. Plant invasions in protected areas: patterns, problemsand challenges, invading nature - springer series in invasion ecology 7, Springer Science+Business Media Dordrecht. 2013.

11. Rzedowski J, Calderón de Rzedowski G. Flora del bajío y de regiones adyacentes: Fascículo complementario XXIV. Instituto de Ecología, A.C. Pátzcuaro Michoacán, México. 2009.
12. Torres-García JR, Segura-León O, Uscanga-Mortera E, et al. Evolution, growth and phenology of Phalarisminor bio types resistant to ACC aseinhibiting herbicides in Mexico. Botanical Sciences. 2018;96(1):95-102.

13. Torres-García JR, Tafoya-Razo JA, Velázquez-Márquez $\mathrm{S}$, et al. Double herbicide-resistant bio types of wild oat (Avena fatua) display characteristic metabolic finger prints before and after applying AC Caseand ALS-inhibitors. Acta Physiologiae Plantarum. 2018;40:119.

14. Storkey J, Neve P. What good is weed diversity?. Weed Research. 2018;58:239-243. 